\title{
Language Learning Motivation of EFL Learners in Japan-A Cross-Sectional Analysis of Various Learning Milieus
}

\author{
Yuzo Kimura \\ Naruto University of Education
}

\author{
Yoshiyuki Nakata \\ Kyushu International University
}

\section{Tomomi Okumura \\ Higashi-Otsu Senior High School}

This study explores the types of language learning motivation possessed by Japanese EFL learners from diverse learning milieus. Research on L2 motivation has long been conducted within the paradigm of social psychology. However, the revival of interest in L.2 motivation in the 1990s shows a clear shift to an educational focus in which L2 learners' cognitive and affective characteristics and classroom considerations have become major areas of concern. Following this trend, the present study employed a 50-item motivational questionnaire based on several motivational components from educational and social psychology. The questionnaire was administered to 1,027 participants from various learning contexts. Exploratory factor analysis confirmed six motivational factors and the follow-up multivariate analysis of variance (MANOVA) indicated that some factors are characteristic of certain language learning milieus, while others are common to all situations. The results are discussed in terms of the motivational characteristics of EFL learners in Japan.

本研究の目的は、多様な学習瀷境を背景とした日本人英語学習者の動機づけ の動向を探ることである。これまで外国語学習の動機づけ研究は、社会心理学の 伜組みからのアプローチが主流であった。しかし、90年代に入ってから、外国 語学習の動機づけ研究には教育面への効果を視野に入れたアプローチが盛んに取 られるようになった。本研究では、社会心理学的および教育心理学的動機づけ理 論を背䍗とした 50 項目から成る質問紙を作成し、様々な学習環境で英語を学習 する 1027 名の被験者を対象として赛施した。因子分析とそれに続く多変量分 散分析の結果、本被験者に固有の6つの動機付け因子が抽出され、被験者の性 差、専攻・学校によってこれらの因子に差異か確認された。これらの結果を基 に、本論では日本人英語学習者の動機の特徽について考察する。 
$\mathbf{M}$ ost language teachers believe that motivation is a key factor for success in language learning. During the last 40 years researchers in various fields have attempted to explore the construct of language learning motivation from many different perspectives. In spite of the number of studies, however, there has been little discussion about what language learning motivation actually is. Dörnyei (1998) notes:

Motivation theories in general seek to explain no less than the fundamental question why humans behave as they do, and therefore it would be naive to assume any simple straightforward answer; indeed, every different psychological perspective on human behavior is associated with a different theory of motivation and, thus, in general psychology it is not the lack but rather the abundance of motivation theories which confuses the scene (pp. 117-118).

Since L2 motivation is a multifaceted construct (Gardner, 1985; Dörnyei, 1998), it is inappropriate for us to seek one theory to explain all aspects of motivation. The term "motivation" is a broad concept that cannot easily be defined. Furthermore researchers often discuss the concept of motivation, whether it is affective, cognitive, behavioral or otherwise, without specifying what kind of motivation they are investigating (Dörnyei, 1998). Thus it is difficult to compare research results across different backgrounds and perspectives.

However it is also true that different theories enable us to look at different aspects of motivation. Therefore, when conducting research and analyzing the data, the particular aspect of motivation addressed needs to be clearly specified. Dörnyei warns that "in the analysis of motivational research, researchers need to be explicit about which aspects of motivation they are focusing on and how those are related to other, uncovered dimensions of the motivational complex" (1999, p. 527 ).

\section{Language Learning Motivation Research}

Gardner and Lambert's early study (1959) indicated that second language achievement is related not only to language aptitude but also to motivation. Their research subjects were English-speaking students in the predominantly French-speaking city of Montreal, Canada. In a subsequent study Gardner and Lambert (1972) suggested that language learning motivation can be divided into two types; integrative motivation, defined as the desire to integrate oneself with the target culture, 
and instrumental motivation, defined as the desire to learn a language for a specific purpose, such as employment. The importance of integrative motivation in second/foreign language learning has received worldwide attention and has become a primary focus of research (Gardner, 1988; Giles \& Byrne, 1982; Schumann, 1978, 1986). However many researchers have tried to analyze language learning motivation without considering the different social contexts in which it occurs. For example some researchers have found instrumental motivation to be a major factor in research conducted in the social contexts of the Philippines, India, and Japan (Gardner \& Lambert, 1972; Lukmani, 1972; Chihara \& Oller, 1978).

Towards the end of the 1980s and into the early 1990 s the research focus turned to the differences between ESL learners (those living within the target language culture) and EFL learners (those studying the target language within their own culture) (Au, 1988; Crookes \& Schmidt, 1991; Dörnyei, 1990). For example Dörnyei (1990) suggested that in EFL contexts, where learners have not had sufficient experience of the target language community, motivational factors such as instrumental motivation should receive special attention. Oxford (1996) also considered that EFL environments differ from the ESL situation and recommended that instrumental motivation be a main focus for research in EFL contexts.

Throughout the 1990s research on language learning motivation incorporated concepts from psychology and organizational research, fields with substantial bodies of motivation research. Deci and Ryan (1985) classified motivation into intrinsic motivation, the desire to engage in activities in anticipation of internally rewarding consequences such as feelings of competence and self-determination, and extrinsic motivation, the desire to engage in activities in anticipation of a reward from outside of and beyond the self. However, Hayamizu (1997) argued that intrinsic and extrinsic motivation are not bipolar and antagonistic, but rather are located on a continuum of motivation types. Williams and Burden (1997) also claimed that motivation results from a combination of different influences. Some are internal, coming from the learner, such as an interest in the activity or a wish to succeed, while others are external, such as the influence of other people. Supporting the perception of motivation as a multifacered complex of factors, Brown (1994) proposed a two-by-two matrix representing the combination of the intrinsicextrinsic dimension with the conventional integrative-instrumental dimension. It is difficult, however, to divide language learning motivation into two distinct types such as integrative-instrumental motivation or intrinsic-extrinsic motivation. Inevita- 
bly there will be some areas where these four types overlap.

In addition to the intrinsic-extrinsic paradigm, other important motivation theories from the field of learner cognition are now being considered-what Dörnyei has termed the Learner Level Component of motivation (Dörnyei, 1994). These include goal-setting theory, attribution theory, and self-efficacy theory. Goal-setting theory argues that performance is closely related to a person's accepted goals (Oxford \& Shearin, 1994). Attribution theory claims that the way people explain their own past successes and failures will significantly affect their future achievement behavior (Weiner, 1985). Self-efficacy theory suggests that people's judgement of their capabilities to carry out specific tasks will affect their choice of the activities attempted (Dörnyei, 1998).

Besides these theories from educational psychology, there is also a large body of research on anxiety in language learning (Bailey, 1983; Horwitz, Horwitz \& Cope, 1986; MacIntyre \& Gardner, 1989, 1991, 1994; Tsui, 1996). Anxiety is an extremely crucial cognitive factor for all types of learners and "a most studied motivational aptitude" (Snow \& Swanson, 1992, p. 600). Clément, Dörnyei, and Noels (1994), for example, found that anxiety or self-confidence is one of the major contributing factors determining attitude and motivation towards learning a second language.

Research on second/foreign language learning motivation in the 1990 s also concentrated on seeking explanations for outcomes of specific language tasks and behaviors rather than pursuing general tendencies in social contexts. In this regard, what Dörnyei proposes as the learning specific level component, including course-specific, teacher-specific and group-specific motivational components (Dörnyei, 1994), should be a subject for extensive research.

\section{Motivation Studies in Japan}

Language learning motivation did not become a major research concern in Japan until quite recently. This may be because learner variables in general have not been a focus in foreign language teaching. In Japan the most popular teaching methods have been teacher-centered rather than learner-centered and classes are usually quite large- 40 to 50 students per class in most high schools and many universities. Thus the motivation of individual learners has received little attention. Furthermore, although there are some recent studies on language learning motivation in Japan (e.g., Konishi, 1990; Matsukawa \& Tachibana, 1996; Miyahara, Namoto, Yamanaka, Murakami, Kinoshita \& Yamamoto, 1997; Sawaki, 1997; Takanashi, 1990, 1991; Yashima, 2000), 
much of this research has used Gardner's approach for investigating motivation in the ESL context and has also regarded Gardner's findings to be applicable to the Japanese EFL situation. However, since Gardner's theory of motivation addresses the social context, not the individual learner, it is suggested that his theory alone cannot explain what motivates language learners in Japan. More attention must be paid to the educational setting when investigating $\mathrm{EFL}$ learning motivation.

To this end, other motivational studies have been conducted using different methodological approaches. For example, in their longitudinal study of attitudes and motivation in English learning among Japanese seventh-grade students, Koizumi and Matsuo (1993) administered the same motivational questionnaire four times and found a decrease in motivation after the initial stage of the learning process. Ogane and Sakamoto (1999) investigated the relationships among EFL motivation and proficiency factors using a structural equation modeling approach. In our pilot study (Kimura, 1999), 390 Japanese university EFL students responded to a 50 -item questionnaire on motivation consisting of items not only based on the integrative-instrumental and intrinsic-extrinsic paradigms, but also on other domains such as anxiety, attribution, and teacher-specific and activity-specific motivation. The present questionnaire-based study continues in this direction and is intended to stimulate motivational research focused on educational aspects in Japan.

\section{Research Questions}

Dörnyei and his colleagues (Dörnyei, 1990; Clément et al., 1994; Dörnyei, 1996) have suggested that there are other aspects of motivation in addition to the ones in Gardner's theory. However, it would be inappropriate to consider that their research results can be fully applied to the Japanese EFL context since little research has been conducted to identify the various motivational components characterizing different learning contexts in Japan. Thus the present study investigates motivational components among Japanese learners of English from differing learning environments, including junior high school, high school, junior college and university classes. The following research questions were addressed:

1. What are some components of EFL motivation possessed by a sample of Japanese EFL learners?

2. Are the components of EFL motivation different for various Japanese learning situations such as junior high school, high school, junior college and university?

3. What motivational differences exist among gender and grade levels in different Japanese EFL learning situations? 


\section{Methods}

\section{Participants}

The participants in this study were 1,027 Japanese EFL students from 12 different learning contexts. Twelve percent were junior high school students, $45 \%$ were senior high school students, $39 \%$ were junior college (130) and university students (397), and the remaining $4 \%$ were students at a private English language school. Although they ranged in age from 14 to $35,64 \%$ were 14 to 18 years old and $30 \%$ were 19 to 22 . The male/female ratio was almost even; $43 \%$ were male and $57 \%$ were female. The participants at the tertiary level were fairly evenly distributed across six majors, that is, junior college English majors, social science majors, science majors, foreign language majors, engineering majors, and English language education majors. The participants comprised a convenience sample since they had been asked to voluntarily fill out the questionnaire by their teachers, who were known by the researchers and who kindly cooperated in the research.

\section{Materials}

The questionnaire used in the present study is a partially revised version of the Japanese-language instrument used for the pilot study (Kimura, 1999). It consisted of 50 items arranged in a 6-point Likert scale format, ranging from strongly disagree to strongly agree. The question items were based on the components of motivation suggested by Schmidt, Boraie, and Kassabgy (1996). However, some items were either modified or newly added based on Clément et al. (1994), Dörnyei (1990), Miyahara et al. (1997), and Tremblay and Gardner (1995) so that the wordings could more precisely describe the EFL contexts in Japan. The following motivational components were addressed: five items about Intrinsic Motivation, six about Extrinsic Motivation, seven about Instrumental Motivation, five about Situation Specific Motivation, four about Teacher Specific Motivation, ten about Activity Specific Motivation, five about Attitudes towards Anglophonic Culture and Integrative Motivation, and eight about Attribution Theory (see Table 1 below).

\section{Procedure and Statistical Analyses}

The questionnaire was administered in Japanese between January and March, 1999 under the supervision of the participants' English teachers. On completion of the data collection, descriptive statistics were computed for all questionnaire items to eliminate skewed items with ceiling and floor effects. The data was then analyzed in two phases. 
First a factor analysis was performed to summarize the underlying characteristics of language learning motivation of this population. This was followed by multivariate analyses of variances (MANOVA) using the factor scores for each motivational factor to investigate the relationship between language learning motivation and learner factors such as gender, academic major, and the institutional grade. Table 1 gives the descriptive statistics for the 50 items.

Table 1: Descriptive Statistics for the 50 Questionnaire Items

\begin{tabular}{|c|c|c|c|}
\hline \# & Questionnaise Items & Мезл & S.D \\
\hline \multicolumn{4}{|c|}{ Intrinsic Motivation } \\
\hline 1 & I study English because ! like it. & 3,375 & 1.576 \\
\hline 2 & If feel satisfaction when I am Ieaming English. & 3.205 & 1.435 \\
\hline 3 & I wish I could learn English without going to school & 3444 & 1.595 \\
\hline 4 & I want to learn any foreign language and as many as possible. & 3.818 & 1633 \\
\hline 5 & I want 10 continue studying English for the rest of my life. & 3.667 & 1.611 \\
\hline \multicolumn{4}{|c|}{ Extrinsic Motivation } \\
\hline 16 & $\begin{array}{l}\text { The main reason I am learning English is that I want my parents/ my teacher to be happy } \\
\text { about it: }\end{array}$ & 1.766 & 1,116 \\
\hline 7 & I am leaming English because English is my compulsory subject. & 3,394 & 1,752 \\
\hline 8 & The mair reason I need to leam English is to pass examinations. & 3378 & 1.678 \\
\hline 9 & $\begin{array}{l}1 \text { an learning English beeause everybody in Japan should be sble to understand English } \\
\text { nowadays. }\end{array}$ & 3.537 & 1.415 \\
\hline 10 & I am leaming English because English is a must for a faparese in the global sociefy. & 3.831 & 1,466 \\
\hline 11 & I wouldn't like to leam English if I didn't have to do so (reverse-coded) & 3.824 & 1.738 \\
\hline \multicolumn{4}{|c|}{ Instrumental Motivation } \\
\hline 12 & I want to leam English because it is useful when traveling in many countries & 3803 & 1.456 \\
\hline 13 & I want to leam English because I want to study abroad in the future. & 2.821 & 1590 \\
\hline 14 & The main reason I am leaming English is that my future job requires the English skills. & 3.224 & 1.644 \\
\hline 15. & $\begin{array}{l}\text { One reason I am learning English is that I can make frends or comespond with people in } \\
\text { foreign couotries. }\end{array}$ & 3.203 & 1657 \\
\hline 16 & If I Jeam English benter. I will be able to get a better job & 3.607 & 1,546 \\
\hline 17 & $\begin{array}{l}\text { The better marks I can achieve in English class, the more chances I wilt get } 10 \text { find an } \\
\text { exciting job. }\end{array}$ & 3.171 & 1459 \\
\hline 18 & Increasing my English proficiency will have a financial benefit for me. & 2.427 & 1348 \\
\hline \multicolumn{4}{|c|}{ Situation Specific Motivarion (Anxiety) } \\
\hline 19 & I feel uncomfortable if I am called on and bave to answer the questions in my English elass. & 3.898 & 1.629 \\
\hline 20 & It embarrasses me to volunteer answers in my English class & 3,907 & 1,577 \\
\hline 21 & I am afraid other students wall laugh at me when I speak English. & 2.908 & 1478 \\
\hline 22 & I think | can learn English well, but I don't perform well on tests and examinations, & 3.345 & 1.428 \\
\hline 23 & If feel uncomfortable when I have to conduct pair or group work in my English elass. & 3.0497 & 1.602 \\
\hline \multicolumn{4}{|c|}{ Teacher Specific Molivation } \\
\hline 24 & I would be encouraged if the leacher 5poke only English during the class. & 3090 & 1.431 \\
\hline$\cdot 25$ & I would find myseif motivated if the teacher had blue eyes and fair hair. & 2.551 & $1 \leq 57$ \\
\hline 26 & $\begin{array}{l}1 \text { woutd be more interested in English if the teachet was a person who patienily explains } \\
\text { difficult matrers of the English language in Japanese. }\end{array}$ & 4.269 & 1.412 \\
\hline 27 & $\begin{array}{l}\text { I would be discouraged if the English teacher had each student read aloud or answer } \\
\text { guestions afver caling on them individually (reverse-coded). }\end{array}$ & 3.231 & 1.556 \\
\hline \multicolumn{4}{|c|}{ Aetivity Specific Motivation } \\
\hline 28 & $\begin{array}{l}1 \text { would be encouraged to leam English if i had more explanations of grammatical points and } \\
\text { Japanese translation. }\end{array}$ & 3.007 & 1.441 \\
\hline 29 & Ilike English learning activities in which sludents work logethor in pairs or small groups. & 3.433 & 1,391 \\
\hline 30 & 1 would like to have a class where only English is spoken. & 2.780 & 1.390 \\
\hline 31 & $\begin{array}{l}\text { In English class, the teacher should do most of the talking while the students shouid only } \\
\text { answer when they are called upon. }\end{array}$ & 2.441 & 1.278 \\
\hline 32 & I prefer to work by myself in English class, not with other students & 2.869 & 1.456 \\
\hline 33 & $\begin{array}{l}\text { Aclivities in the class should be designed to help the students imptove their abilities to } \\
\text { communicate in English. }\end{array}$ & 3912 & 1506 \\
\hline$\cdot 34$ & Group activities and pair work in English class are a waste of time. & 2.243 & 1.326 \\
\hline 35 & In my English class, I want to read English novels or English news articles. & 3,478 & 1,452 \\
\hline$\bullet 36$ & $\begin{array}{l}\text { In my English class, I enjoy learning when emphasis is put on such things as movies or } \\
\text { music. }\end{array}$ & 4878 & 1.260 \\
\hline
\end{tabular}




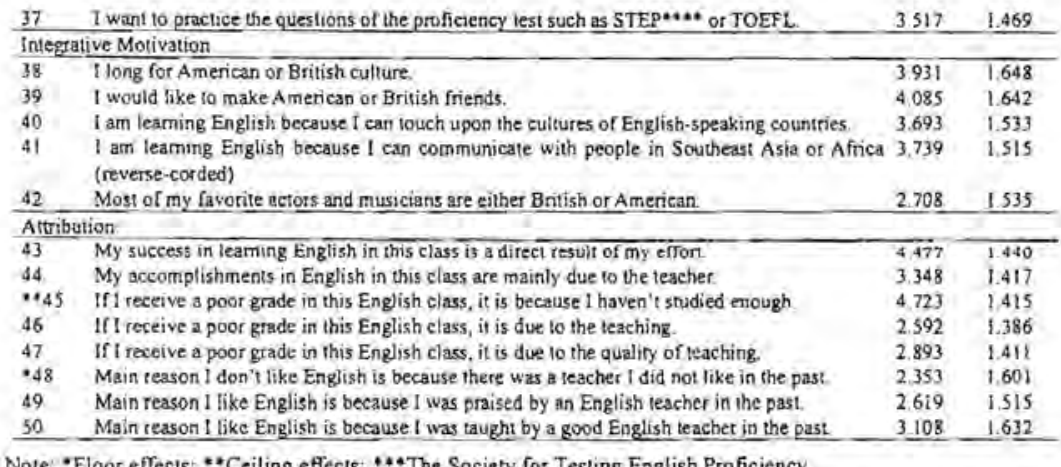

Examination of the mean and standard deviations for the 50 items revealed that four items were left-skewed and two items were rightskewed. The left-skewed items, or the items to which the participants responded extremely negatively, include Items 6 (The reason for studying English is to make parents or teachers happy.), 25 (The appearance of teachers such as blue eyes or fair hair motivates one's English language learning.), 34 (Pair or group activities are a waste of time.) and 48 (One's dislike of English can be attributed to the existence of repulsive teachers.). The right-skewed items were Items 36 (I want English class to be enjoyable by incorporating activities such as watching movies and singing songs.) and 45 (Poor results can be attributed to poor devotion to study.). The participants responded to these items to an extremely positive degree. Therefore, the six skewed items were excluded from further analysis. Statistical analyses were conducted using SPSS10.07 (1999). Cronbach's alpha statistics were computed for the 44 remaining questionnaire items and a reliability of .865 was obtained.

\section{Results}

\section{Some Components of Motivation in the Japanese EFL Context}

Using the Principal Factors procedure and Varimax Rotation, six factors were extracted. Table 2 presents the factor matrix with an item loading greater than .40 as the criterion of salience. These factors accounted for $50.42 \%$ of the variance in the 44 items.

Factor 1 received appreciable loadings from 13 items, the largest component of language learning motivation for this sample. As shown in Table 2 , the variables for this factor were quite diverse. Four items 
$(39,40,38,41)$ relate to integrative motivation, while others $(15,13$, $12,14)$ concern instrumental motivation. Still others $(5,4,3)$ relate to intrinsic motivation. Thus this factor is called Intrinsic-InstrumentalIntegrative Motive.

Factor 2 received loadings from six items $(9,17,8,18,7,37)$. Items 9,8 and 7 are concerned with extrinsic motivation, while Items 17 and 18 are typical of instrumental motivation. Therefore, this factor can be labeled Extrinsic-Instrumental Motive.

Table 2: Results of Factor Analysis for All Subjects $(n=1,027)$

\begin{tabular}{|c|c|c|c|c|c|c|c|c|}
\hline ilem \# & Questionnaire liems & FI & F2 & $F_{3}$ & F4 & Fs & F6 & $k^{\prime}$ \\
\hline 39 & Want to make American or British friends. & 809 & & & & & & .668 \\
\hline 40 & To touch upos the culture of English-speaking countries. & $\operatorname{sos}$ & & & & & & 706 \\
\hline is & To make friends or correspond with people in foreign countries. & 704 & & & & & & 591 \\
\hline 38 & Long for A merican or British culture. & 586 & & & & & & 554 \\
\hline \$1 & To communicale with people in Southeast Asia of Africa. & .685 & & & & & & 560 \\
\hline$s$ & TVani to continue studying English for the rest of my life. & 647 & & & & & & 700 \\
\hline 13 & To study abroad in the future. & 623 & & & & & & 522 \\
\hline 4 & Went to learn any foreign language (as meny as possible). & 616 & & & & & & 483 \\
\hline 33 & Activities should be 10 improve communication skills in English. & $5: 5$ & & & & & & 528 \\
\hline 11 & Would not learn English ifl didn't have to do so (reverse-coded). & 504 & & & & & & 558 \\
\hline 12 & Useful when traveling in many countries. & 500 & & & & & & 405 \\
\hline 14 & My future job requires English skills. & 483 & & & & & & 584 \\
\hline 3. & Wish I could leam English without going to school. & 439 & & & & & & 326 \\
\hline 9 & Everybosdy in Japan should be able to understand English nowadays & & 647 & & & & & 546 \\
\hline 17 & To find an exciting job. & & 574 & & & & & 522 \\
\hline 8 & To pass examinations. & & .553 & & & & & .484 \\
\hline is & To have a financial benefit for me. & & 517 & & & & & .440 \\
\hline 7 & Because English is a compulsory subject. & & .481 & & & & & 429 \\
\hline 37. & Want to practice the questions for the proficiency test & & 449 & & & & & 290 \\
\hline so & Like English becsuse taught by a good English teacher. & & & 540 & & & & 421 \\
\hline 49 & Like English because praised by an English teacher before. & & & 515. & & & & 374 \\
\hline 20 & It embarrasses me to volunteer answers in my Eoglish class. & & & & 753 & & & 581 \\
\hline 19 & Feel uncomfortable if colled on to answer questions in class. & & & & .721 & & & $5 \Omega 2$ \\
\hline 21 & 1 an afraid other students will taugh at me when I speak English & & & & .534 & & & 362 \\
\hline 22. & 1 don't perform well on tests and examinations. & & & & 448 & & & 239 \\
\hline 32 & Prefer to work alone in English class. & & & & & 733 & & 440 \\
\hline 29 & Fond of pair or group activities. & & & & & -582 & & 503 \\
\hline .31. & Fond of leacher-centered lectures & & & & & 575 & & 307 \\
\hline 47 & Poor grade in this class can be attributed to the quality of the teacbing. & & & & & & 824 & $5 \$ 3$ \\
\hline \multirow[t]{4}{*}{46} & Poor grade in this class can be attributed to the quality of the teacher. & & & & & & .776 & 547 \\
\hline & Eigenualue & 10.30 & 4,51 & 2.05 & 1.98 & 1.75 & 1.58 & \\
\hline & Percentage of Veriance & 23,42 & 30.25 & 467 & 4.51 & 3.99 & 3.59 & \\
\hline & Cumulnive Percentage of the Toral Variance & 23,42 & 33.66 & 3833 & 4284 & 46.82 & 50.42 & \\
\hline
\end{tabular}


Factor 3 received loadings from two items $(50,49)$, both of which relate to positive aspects of teachers. Therefore this factor can be termed Influence of Good Teachers.

The four items of Factor 4 all relate to anxiety in language learning. Using the terminology of Horwitz et al. (1986), Items 20 and 19 are called Communication Apprehension, Item 21 is interpreted as Fear of Negative Evaluation and Item 22 is Test-Anxiety. These items connote negative anxiety, also known as debilitative anxiety, compared with the positive form of anxiety termed facilitative anxiety (Brown, 1994). Following Dörnyei (1994), this factor is therefore called Language Use Anxiety.

Factor 5 is characterized by heavy loadings from three items $(32,29$, 31). Though they are all related to classroom activities, Items 32 and 31 have positive loading values, indicating a preference for teacher-centered lectures, whereas Item 29 has a negative value, implying an unwillingness to participate in pair or group activities. Therefore, this factor can be called Preference for Teacher-Centered Lectures.

Factor 6 obtains appreciable loadings from two items $(47,46)$ implying a negative inclination towards learning language due to past unpleasant experiences. Considering Weiner's (1985) Attribution Theory, Nakata (1999) suggests that learners scoring high on this factor can still maintain their self-worth and control their effort. This factor is labeled Negative Learning Experiences.

\section{Differences among the Components of Motivation in Various Japanese EFL Milieus}

The six factor scores were submitted to one-way multivariate analysis of variance (MANOVA) as dependent variables with participants' institutions or majors as independent variables. All multivariate Fstatistics (i.e., Pillai's trace, Wilks' lambda, Hotelling's trace, and Roy's largest root) were significant at the .001 alpha level. Therefore, univariate analysis variance was run for the six dependent variables. The univariate $F$ values of all factors except Factor 5 and Factor 6 were significant at the ,001 alpha level (see Table 3).

Table 3: Results of Univariate Analysis of Variance and Mean Factor Scores

\begin{tabular}{lcccccccccc}
\hline & $F(8,1018)$ & JHS & SHS & JC & SO & SC & FL & EG & ED & LS \\
\hline Factor 1 & $13.694 * * *$ & 186 & -.253 & .355 & -.002 & -.313 & .569 & -.575 & .436 & .482 \\
Factor 2 & $13.047 \cdots *$ & .597 & -.113 & -.010 & .291 & .213 & -.334 & .468 & -.406 & -719 \\
Factor 3 & $17.744 \cdots *$ & -.071 & -.310 & .488 & -.005 & -.012 & .568 & -.234 & .862 & .631 \\
Factor 4 & $7.743 * * *$ & -.182 & .176 & .079 & -.033 & .352 & -.615 & -.128 & -.135 & -.372
\end{tabular}


$\begin{array}{lllllllllll}\text { Factor } 5 & 2.690^{*} & -.079 & .083 & .075 & -.027 & -.055 & -.162 & .182 & -.146 & -.132\end{array}$

$\begin{array}{llllllllllll}\text { Factor } 6 & 1.931 & -.092 & .038 & .170 & .029 & -.016 & 190 & -.091 & -.141 & -.382\end{array}$

Note. JHS $=$ junior high school $(n=124)$; SHS=senior high school $(n=461)$; JC $=$ junior college $(n=130)$, SO= social $(n=83)$; SC - Science $(n=34)$; FL=Foreign language $(n=85)$; EG=engineer $(n=40)$; ED=education (English major) $(n=25) ; L S=$ language $3 \operatorname{chool}(n=45)$

Posthoc Scheffe's test revealed that there were several significant pairs among the factors from Factor 1 to Factor 4 . Table 4 summarizes these results.

Table 4: Summary of Post-hoc Scheffé's Test

\begin{tabular}{|c|c|}
\hline Factors & Post hoc (Scheffe's test) Results \\
\hline Factor 1 & 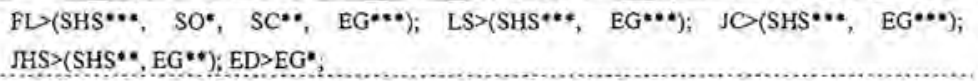 \\
\hline Eactor 2 & 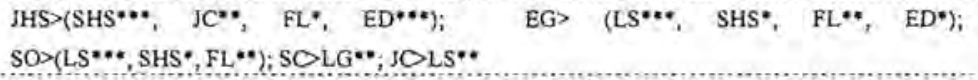 \\
\hline Factor 3 & 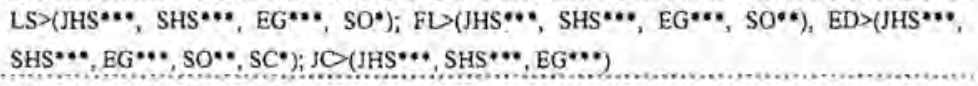 \\
\hline Factor 4 & 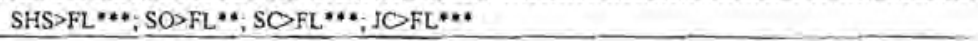 \\
\hline
\end{tabular}

The results of Table 4 are further summarized in Table 5 to reveal the relationship between each motivational factor and category. The summary identifies pairs with a relationship at the .001 significance level.

Table 5: Conceptual Summary of Motivational Factors

\begin{tabular}{|c|c|c|c|c|c|c|c|c|c|}
\hline & JHS & SHS & JC & so & SC & FL & EG & ED & LS \\
\hline $\begin{array}{l}\text { Intrinsic-Instrumental-Integrative } \\
\text { Motive }\end{array}$ & + & - & + & & & + & - & & + \\
\hline Extrinsic-Instrumental Motive & + & - & & - & & & + & - & - \\
\hline Influence of Good Teachers & - & - & + & & - & + & - & + & + \\
\hline Language Use Anxiety & & + & + & & + & - & & & \\
\hline
\end{tabular}

Table 5 indicates that Factor 1 (Intrinsic-Instrumental-Integrative Motive) was high among junior high school learners, junior college English majors, foreign language majors, and English language school learners. Since these subjects are either learners at the early stages of 
their learning experience or have clear goals for learning English, it appears that such learners tend to be motivated by a combination of intrinsic, instrumental, and integrative concerns. On the other hand, Factor 2 (Extrinsic-Instrumental Motive) is positive only among junior high learners and engineering majors and is negative for senior high learners, social science majors, education majors, and those studying at a language school. Engineering majors apparently tend to study English for more extrinsic and pragmatic reasons than those who feel they need English for their future careers, such as students majoring in English education and those studying at an English language school. Table 5 also indicates that learners who are familiar with English or need English for their careers (e.g., junior college English majors, university students majoring in English as a foreign language, and those studying English at a language school) felt that their teachers had a positive influence on their learning process while those in secondary school or those majoring in science or engineering did not. Finally, learners majoring in English as a foreign language reported less anxiety in the classroom than senior high students, junior college English majors, or social science majors.

\section{Motivational Differences According to Gender and Grade Level}

In order to investigate motivational differences with regard to gender and grade level, a 2 (male and female) by 6 (grade level) two-way MANOVA was performed with the six factor scores as dependent variables. The analysis confirmed that all multivariate Fstatistics (i.e., Pillai's trace, Wilks' lambda, Hotelling's trace and Roy's largest root) for the two main effects of gender and grade as well as interaction effects were significant (see Table 6). Therefore, a univariate analysis of variance for gender and grade interaction was performed to see which dependent variables were significant. As is shown in Table 7, only Factor 5 (Preference for Teacher-centered Lectures) was significant at the 005 level.

Table 6: Results of Two (Gender) by Six (Grade) Two-way MANOVA

\begin{tabular}{lccccc}
\hline & Value & F & Hypothesis df & Error df & Sig- \\
\hline Gender (A) & & & & & \\
Pilla's trace & .094 & 15.484 & 6 & 897 & .000 \\
Wilks' lambda & .906 & 15.484 & 6 & 897 & .000 \\
Hotteling's trace & .104 & 15.484 & 6 & 897 & .000 \\
Roy's largest root & .104 & 15.484 & & 897 &
\end{tabular}




$\begin{array}{lrrrrr}\text { Grade Level (B) } & & & & & \\ \text { Pilla's trace } & .240 & 7.585 & 30 & 4505 & .000 \\ \text { Wilks' lambda } & .776 & 7.840 & 30 & 3590 & .000 \\ \text { Honteling's trace } & .269 & 8.014 & 30 & 4477 & .000 \\ \text { Roy's largest root } & .166 & 24.999 & & 901 & \\ & & & & & \\ \text { Ax B } & .061 & 1.853 & 30 & 4505 & .003 \\ \text { Pilla's trace } & .940 & 1.859 & 30 & 3590 & .003 \\ \text { Wilks' lambda } & .062 & 1.862 & 30 & 4477 & .003 \\ \text { Hotreling's trace } & .033 & 4.904 & 6 & 901 & 000 \\ \text { Roy's largest root } & & & & \end{array}$

Table 7: Univariate ANOVA for Gender and Grade Interaction

\begin{tabular}{ccccccc}
\hline Source & $S S$ & $d f$ & $M S$ & $F$ & $\rho$ \\
\hline Factor 1 & 6.726 & 5 & 1.345 & & 1.730 & .25 \\
Factor 2 & 6.961 & 5 & 1.392 & 1.897 & .092 \\
Factor 3 & 5.352 & 5 & 1.070 & 1.672 & .139 \\
Factor 4 & 4.424 & 5 & .885 & 1.168 & .323 \\
Factor 5 & 12.891 & 5 & 2.578 & 3.350 & .005 \\
Factor 6 & 5.576 & 5 & 1.115 & 1.348 & .242 \\
\hline
\end{tabular}

The descriptive statistics for Factor 5 are shown in Table 8 and the results are graphically summarized in Figure 1.

Table 8: Descriptive Statistics for Factor 5

\begin{tabular}{llcccc}
\hline & & $n$ & $M$ & $S D$ \\
\hline Male & $J 3$ & 62 & .008 & 1.019 \\
& SHS 1 & 61 & -.039 & .893 \\
& SHS 2 & 122 & .381 & .847 \\
& SHS 3 & 55 & -046 & .869 \\
& Univ 1 & 106 & -090 & .910 \\
& Univ 2 & 13 & -.119 & .618 \\
Female & J3 & 62 & -.165 & .984 \\
& SHS 1 & 53 & -.025 & .931 \\
& SHS 2 & 144 & -.030 & .850 \\
& SHS 3 & 25 & .016 & .904 \\
& Univ 1 & 137 & .113 & .765 \\
& Univ 2 & 74 & -182 & .886 \\
\hline
\end{tabular}

Nole. $\mathrm{M}=$ male $(n=419) ; \mathrm{F}=$ fermale $(n=495) ;$ JHS3-junior bigh school $3^{\text {rd }}$ year $(n=124) ;$ SHS1=senior high school $1^{\text {un }}$ year $(n=114)$; SHS2 $=$ senior high school $2^{\text {pd }}$ year $(n=266)$; SHS $3=$ senior high school $3^{\text {nd }}$ year $(n=80)$; Univl=University $1^{n}$ year $(n-243)$; Univ 2-University $2^{\text {od }}$ year $(n=87)$.

Due to the small number of participants, university $3^{\text {rt }}$ and $4^{\text {th }}$ year students as well as language school participants were exciuded from the analysis. 
Figure 1: Interaction Plot for Factor 5

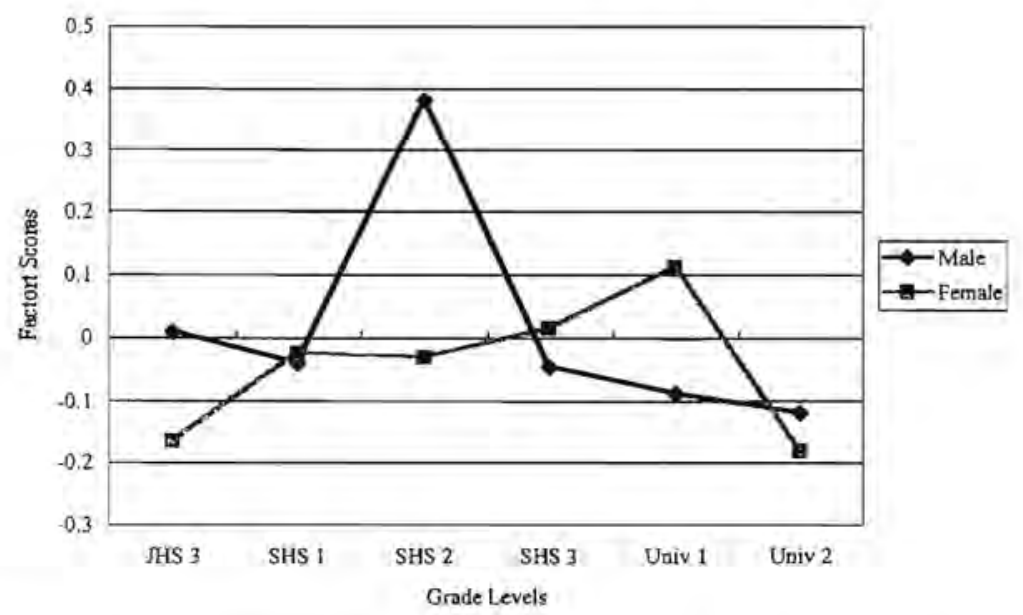

Examination of Figure 1, the interaction plot for Factor 5 as determined by a posthoc contrast (Scheffé test), revealed that the second year male high school participants significantly preferred teacher-centered lectures. This outcome is somewhat perplexing. However the sample of second year high school students used here was taken from three different schools with somewhat different academic expectations. Two of the schools are considered to be fairly academic while the remaining one is not, which may account for this result Further studies are necessary to clarify this point.

\section{Discussion and Pedagogical Implications}

This study has attempted to identify the characteristics of foreign language motivation possessed by a range of EFL learners in Japan. The largest factor of language learning motivation observed is complex, consisting of intrinsic, integrative and instrumental subscales. This complexity is consistent with the findings of Koizumi and Matsuo (1993) and Matsukawa and Tachibana (1996), who suggest that there are multiple factors of language learning motivation among Japanese junior high school EFL students. The complexity of the first factor accurately reflects the lack of a single motivational factor among the present subjects as well, and may be evidence of the difficulty that many teachers report in motivating Japanese EFL learners. Comparative studies on learning styles such as Reid's (1987) have indicated Japanese learners' lack of predominant learning styles in comparison to 
learners of other nationalities. The present findings support the implication that Japanese learners may be not so easily motivated to learn foreign languages.

However, a close examination of each questionnaire item for this factor (Table 2) shows that there seem to be three fairly distinct dimensions of "integrativeness." Items 39 (Want to make American or British friends) and 38 (Long for American or British culture) can be defined as Attitudes Towards Anglophonic Culture, whereas Items 40 (To touch upon the culture of English-speaking countries), 15 (To make friends or correspond with people in foreign countries), and 41 (To communicate with people in Southeast Asia or Africa) [negative loading] are similar to Gardner's (1985) definition of the integrative motive, also involving to some extent Graham's assimilative motivation (Graham, cited in Brown, 1994, p. 155). On the other hand, Items 12 (Useful when traveling in many countries) and 33 (Activities should be to improve communication skills in English.) can be described as the "friendship orientation" or "travel orientation" described by Clément and Kruidenier (1985), since opportunities for communication in a foreign language can easily be found while traveling in foreign countries.

Further interpretation of the items in Factor 1 and 2 in relation to their original subscales of motivation in our questionnaire reveals another characteristic about EFL instrumental motivation in Japan. Items 15 (To make friends or correspond with people in foreign countries), 13 (To study abroad in the future), and 12 (Useful when traveling in many countries) were originally clustered on the instrumental subscale. However, as suggested above, these items seem to have a more integrative connotation when taken together with the other questionnaire items in Factor 1 . This is a very different characteristic from that of the items originally clustered on the same instrumental subscale but located in Factor 2, such as Item 17 (To find an exciting job) or 18 (To have a financial benefit), which have stronger pragmatic connotations. The fact that items originally clustered in the same category as instrumental motivation exist in separate factors with slightly different connotations-the ones in Factor 1 being more integratively oriented and the ones in Factor 2 being more instrumental in a pragmatic senseimplies that the instrumental motivation found in the present study has multifaceted aspects. Gardner and Macintyre (1991) describe two distinct kinds of instrumental motivation as follows:

To the extent that an instrumental motive is tied to a specific goal, however, its influence would tend to be maintained only 
until that goal is achieved... On the other hand, if the goal is continuous, it seems possible that an instrumental motivation would also continue to be effective (pp. 70-71).

In the present study, however, the subscale items for instrumental motivation located in Factor 1 (Items 15, 13, and 12) might apply to cases related to continuous goals. Making foreign friends or going abroad for study or sightseeing purposes often requires learners to set long-term goals. On the other hand, the more pragmatic subscale items located in Factor 2 (ttems 17 and 18) might be tied to a specific goal because finding an exciting job or receiving financial benefits relate more to short-term goals.

The existence of Factor 3 (Influence of Good Teachers) suggests that learners may attribute their success in learning a foreign language to their teachers. This result may seem to contradict Factor 5 which represents bad learning experiences caused by teachers or their teaching. However, this apparent contradiction can be interpreted as the opposite sides of the same coin. Teachers in a non-ESL setting such as Japan may have a greater influence on their learners in both positive and negative ways than ESL teachers. Unlike the ESL context, where learners are exposed to the target language outside of class, teachers in the Japanese EFL context tend to be the main provider of English due to the absence of a target language community.

Another finding, Factor 4 (Language Use Anxiety), is also worthy of mention. Anxiety is usually considered to influence the language learning process. For example, Tsui's (1996) qualitative data analyses of reticence in Hong Kong EFL classes illustrate how language learning anxiety among Chinese students hinders their classroom interactions. According to Tsui, students did not take the initiative or answer questions until they were asked by the teacher to do so. Although the students knew the answers, they felt anxious and did not want "to give their peers the impression that they are showing off" (Tsui, 1996, p. 158). It would be beneficial for teachers in the similar Japanese EFL setting to adopt the classroom strategies specified by Tsui (1996) such as "improving questioning technique," "accepting a variety of answers," and "peer support and group work or focus on content" (Tsui, 1996, pp. 161-163). It is also crucial for EFL teachers to create a comfortable classroom environment and to establish good relationships with their students, and thereby minimize negative anxiety.

Factor 5 (Preference for Teacher-centered Lectures) and Factor 6 (Negative Learning Experiences) were both shown to be motivational factors for EFL learners in Japan. Both of these factors as well as Factor 
3 (Language Use Anxiety) are negative aspects in learning foreign languages. For example, those who have had negative experiences due to poor teachers or teaching may have high negative anxiety. Such learners may be inactive in class and may have lost interest in learning the foreign language. As a result, they may prefer passive or teacher-led language classes. Providing these learners with extracurricular opportunities may be one way to assist them to overcome their anxiety and negative feelings. For example, class journals for students or an e-mail bulletin board on the teacher's website can expand the chances of communication between teachers and learners.

A second purpose of this study was to investigate motivational factors present within different learning contexts. The major finding here is that those learners who need English skills for their present or future careers tend to be motivated intrinsically and integratively as well as instrumentally. One interesting phenomenon (Table 5) is that different motivational patterns can be observed for junior and senior high school learners. Both Factor 1 (Intrinsic-Instrumental-Integrative Motive) and Factor 2 (Extrinsic-Instrumental Motive) are high among junior high school 3rd year learners yet both were low among senior high school learners. This result suggests that junior high school learners are highly motivated compared to senior high school learners. However, in this sample, all of the 3rd year junior high school students attended a school attached to a national university of education and had been screened by strict entrance examinations. Under such circumstances, it is not surprising that the present junior high school students showed high motivation scores. This finding must be confirmed by studies with different populations of junior and senior high school learners.

Another explanation can be found in the difficulty of holding learners' interest in studying English for a long period of time. While Japanese junior high school EFL learners are usually enthusiastic about English at least during the first semester of their first year, they start exhibiting unwilling attitudes towards learning English during the first semester of their second year (Hatori \& Matsuhata, 1980). Another nationwide survey shows that 30.8 percent of high school students expressed an unwillingness to study English (Matsuura, Nishimoto, Ikeda, Kaneshige, Ito \& Miura, 1997). These results support the suggestion that the senior high school EFL learners in the present study were less motivated than those in junior high school.

The final goal of this study was to explore motivational differences with regard to gender and grade levels. However, based on the results of the multivariate analyses of variance, interpretation of the signifi- 
cant interaction of gender and grade for Factor 5 (Preference for Teacher-centered Lectures) is difficult. One possible explanation for the high scores of the high school 2nd year male students is that they were particularly well motivated in terms of preparing for entrance examinations, and were willing to listen to English lessons presented in a lecture style. As mentioned, the high schools from which these students were drawn were relatively high in terms of academic level. As to why the female students from the same schools did not show the same results, it is necessary to wait until more research is conducted.

\section{Conclusion}

The findings from this study of a large sample of Japanese EFL learners from various learning milieus support several suggestions which have been made about language learning motivation. The data clearly indicates that the largest motivational factor in English language learning among Japanese EFL students is complex, with both intrinsic and integrative characteristics. What has been defined as instrumental motivation in the ESL context was also found to be the second largest motivational component among the present EFL learners, but in the Japanese context instrumentality itself seems to be multifaceted in nature.

The present data also suggests that Japanese EFL leamers have inhibitory factors operating against learning English such as anxiety, past negative experiences, or preferring teacher-dominated lectures. However the learners also hold an affirmative motivational factor recognizing the role of teachers in facilitating successful learning. These findings imply that EFL teachers should pay careful attention to their students, not only from a narrow pedagogical standpoint, but also in terms of human relations between learners and facilitators.

There are at least four areas that should be investigated in future research. First, the survey should be redesigned to include a more careful selection of items. Although the items in the present investigation were developed based on previous studies, with some items being directly adopted and others being modified or newly created, all items did not necessarily perform well. For example, although items such as Item 25 (The appearance of teachers such as blue eyes or fair hair motivates one's English language learning) were included because of the existence of this attitude elsewhere (for example, Suzuki, 1999), the item was extremely negatively skewed, meaning that Japanese EFL learners may no longer possess this sort of appearance-related xenophilic motivation for English learning.

Second, the motivation sub-categories should be reconsidered. Al- 
though the present questionnaire incorporated motivational components based on research in educational psychology, such as attribution, anxiety, and teacher-specific and activity-specific motivation, ample room is left for other components to be included.

Third, the relationships among motivational factors should be explored more fully. One way to analyze this is to employ a structural modeling approach to the present data. Finally, as Fotos (1994) notes, the research methodologies used to study language learning motivation should be more diverse. Research in this area "has been typically conducted using survey methods that have varied little since Gardner published his general research design in $1968^{\prime \prime}$ (Fotos, 1994, p. 44). However, it is insufficient to merely replicate this research, relying only on numerical data. Rather, future study should employ plural methods of data collection, including qualitative methods such as ethnographic classroom observation, classroom discourse protocol analysis, and diary analysis.

\section{Acknowledgements}

This paper is a revised version of a presentation made at AILA 99, Waseda University, Tokyo, on August 2, 1999. We would like to express our sincere gratitude to our colleagues and their students who devoted their time to our research project. We would also like to thank Charlie Canning of Naruto University of Education and the two anonymous reviewers of JALT Journal for their insightful comments on the earlier draft of this paper.

Yuzo Kimura, past JALT Kobe Chapter President, is an associate professor at Naruto University of Education, His research interests include the role of metacognition in L.2 learning and language learning motivation. E-mail: ykimura@naruto-u.ac.jp.

Yoshiyuki Nakata is an associate professor at Kyushu International University, His research interests are language learning motivation and listening strategies. E-mail: nakata@econ.kiu.ac.jp.

Tomomi Okumura is an English teacher at Higashi-Otsu High School in Shiga. Her present research focus is the motivation of Japanese learners of English.

\section{References}

Au, S. Y. (1988). A critical appraisal of Gardner's social-psychological theory of second-language (L2) learning. Language Learning, 38 (1), 75-100.

Bailey, K. M. (1983). Competitiveness and anxiety in adult second language 
learning: Looking at and through the diary studies. In H. W. Selinger \& M. H. Long (Eds.), Classroom oriented research in second language acquisition (pp. 67-102). Rowley, MA: Newbury House.

Brown, H. D. (1994). Principles of language learning and teaching (3rd ed.). Englewood Cliffs, NJ: Prentice Hall Regents.

Chihara, T., \& Oller, J. W. (1978). Attitudes and attained proficiency in EFL: A sociolinguistic study of adult Japanese speakers. Language Learning, 28 (1), $55-68$.

Clément, R., Dörnyei, Z., \& Noels, K. A. (1994). Motivation, self-confidence, and group cohesion in the foreign language classroom. Language Learning. $44(3), 417-448$.

Clément, R., \& Kruidenier, B. G. (1985). Orientations in second language acquisition I: The effects of ethnicity, milieu, and target language on their emergence. Language Learning, 33 (3) 273-291.

Crookes, G., \& Schmidt, R. W. (1991). Motivation: Reopening the research agenda. Language Learning, 41(4) 469-512.

Deci, E. L., \& Ryan, R. M. (1985). Intrinsic motivation and self-determination in human behavior. New York: Plenum Press.

Dörnyei, Z. (1990). Conceptualizing motivation in foreign-language learning. Language Learning, 40(1) 45-78.

Dörnyei, Z. (1994). Motivation and motivating in the foreign language classroom. Modern Language Journal, 78 (3), 273-284.

Dörnyei, Z. (1996). Moving language learning motivation to a larger platform for theory and practice. In R. L. Oxford (Ed.), Language learning motivation: Pathways to the new century (pp. 71-80). Honolulu: University of Hawai'i Press.

Dörnyei, Z (1998). Motivation in second and foreign language learning. Language Teaching, 31(3), 117-135.

Dörnyei, Z. (1999). Motivation. In B. Spolsky (Ed.), Concise encyclopedia of educational linguistics. Oxford: Elsevier.

Fotos, S. (1994). Motivation in second language learning pedagogy: A critical review. Senshu University Annual Bulletin of the Humanities, 24, 29-54.

Gardner, R. C. (1985). Social psychology and second language learning: The role of attitudes and motivation. London: Edward Arnold.

Gardner, R. C. (1988). The socio-educational model of second-language learning: Assumptions, findings, and issues. Language Leaming, 38 (1), 101126.

Gardner, R. C., \& Lambert, W. E. (1959). Motivational variables in second language acquisition. Canadian Joumal of Psychology, 13, $266-272$.

Gardner, R. C., \& Lambert, W. E. (1972). Attitudes and motivation in second language learning. Rowley, MA: Newbury House.

Gardner, R. C., \& Macintyre, P. D. (1991). An instrumental motivation in language study: Who says it isn't effective? Studies in Second Language Acquisition, 13, 57-72.

Giles, H., \& Byme, J. L. (1982), An intergroup approach to second language 
acquisition. Journal of Multicultural and Multilingual Development $3,7-40$.

Hatori, H. \& Matsuhata, K. (1980). Gakushusya chushin no eigo kyoiku [Learnercentered English language education] Tokyo: Taishukan Shoten.

Hayamizu, T. (1997). Between intrinsic and extrinsic motivation: Examination of reasons for academic study based on the theory of intemationalization. Japanese Psychological Research, 39 (2), 98-108.

Horwitz, E. K., Horwitz, M. B., \& Cope, J. (1986). Foreign language classroom anxiety. Modern Language Journal, 70 (2), 125-132.

Kimura, Y. (1999). Gaikokugo gakusyuu ni okeru doukizuke [Foreign language learning motivation]. Naruto English Studies, 12 \& 13, 1-12.

Koizumi, R., \& Matsuo, K. (1993), A longitudinal study of attitudes and motivation in learning English among Japanese seventh-grade students. Japanese Psychological Research, 35 (1), 1-11.

Konishi, M. (1990), Changes in motivation for English language learning: A series of four measurements. The IRLT Bulletin, 4, 1-23.

Lukmani, Y. M. (1972). Motivation to learn and language proficiency. Language Learning, 22 (2), 261-273.

Macintyre, P. D., \& Gardner, R. C. (1989). Anxiety and second-language leaming: Toward a theoretical clarification. Language Leaming, 39 (2), 251-275.

Macintyre, P. D., \& Gardner, R. C. (1991). Investigating language class anxiety using the focused essay technique. Modern Language Joumal, 75 (3), 296 304 .

MacIntyre, P, D., \& Gandner, R. C. (1994). The subtle effects of language anxiety on cognitive processing in the second language. Language Learning, 44 (2), 283-305.

Matsukawa, R, \& Tachibana, Y. (1996), Junior high school students' motivation towards English learning. Annual Review of English Language Education, 7, 49-58. The Federation of English Language Education Societies in Japan.

Matsuura, N., Nishimoto, M., Ikeda, S., Kaneshige, N., Ito, A., \& Miura, S. (1997). Kokosei no eigo gakushu ni kansuru ishiki chosa [A survey on the attitudes of high school students towards English language learning]. The English Teachers' Magazine, 46(7), 4463.

Miyahara, F., Namoto, M., Yamanaka, H., Murakami, R., Kinoshita, M., \& Yamamoto, H. (1997). Konamamade yoinoka daigaku eigo kyouiku [The current concerns on English language teaching at colleges and universities]. Tokyo: Shouhakusha.

Nakata, Y. (1999). Gengogakusyu motivation: Riron to jissen [Language learning motivation: Theory and practice]. Tokyo: Liber Press.

Ogane, E., \& Sakamoto, M. (1999). SEM: Relationships among EFL motivation and proficiency factors. Temple University of Japan Working Papers in Applied Linguistics, 14 [On-line]. Available: http://www.tuj.ac.jp/tesol/press/ papers 0014/ oganeetal.html

Oxford, R. L. (1996). New pathways of language learning motivation. In R. L. Oxford (Ed.), Language learning motivation: Pathways to the new century (pp.1-8). Honolulu: University of Hawai'i Press. 
Oxford, R., \& Shearin, J. (1994). Language learning motivation: Expanding the theoretical framework. Modem Language Joumal, 78 (1), 12-28.

Reid, J. (1987). The learning style preferences of ESL students. TESOL Quarterly, 24 (2), 323-338.

Sawaki, X. (1997). Japanese learners' language learning motivation: A preliminary study. JACET Bulletia, 28, 83-96.

Schmidt, R., Boraie, D., \& Kassabgy, O. (1996). Foreign language motivation: Internal structure and external connections. In R. L. Oxford (Ed.), Language learning motivation: Pathways to the new century (pp. 9-70). Honolulu: University of Hawai'i Press.

Schumann, J. H. (1978). The acculturation model for second language acquisition. In R. C. Gingras (Ed.), Second language acquisition and foreign language teaching (pp. 27-50). Arlington VA: Center for Applied Linguistics.

Schumann, J. H. (1986). Research on the acculturation model for second language acquisition. Joumal of Multilingual and Multicultural Development, 7, 379-392.

Snow. R. E., \& Swanson, J. (1992). Instructional psychology: Aptitude, adaptation, and assessment. In M. R. Rosenzweig \& L. W. Porter (Eds.), Annual Review of Psychology, 43, 583-626,

SPSS Inc. (1999). SPSS Statistical Software Package (Release 10.0J for Windows) [Computer Software]. Tokyo: SPSS Japan Inc.

Suzuki, T. (1999). Nihonjin wa naze eigoga dekinaika (Why can't Japanese speak English?]. Tokyo: Iwanami Shoten.

Takanashi, Y. (1990). Gaikokugo gakusyu ni okeru doukizuke no yakuwari [The role of motivation in foreign language learning]. Bulletin of Fukuoka University of Education, 39 (1), 59-73.

Takanashi, Y. (1991). Eigo gakushyu ni okeru togoteki doukizuke to doguteki doukizuke no yakuwari [The role of integrative and instrumental motivation in English language learning]. Bulletin of Fukuoka University of Education, $40(1), 53-60$.

Tremblay, P. F, \& Gardner, R. C. (1995). Expanding the motivation construct in language learning. Modern Language Journal, 79 (4), 505-520.

Tsui, A. B. M.(1996). Reticence and anxiety in second language learning. In K. M. Bailey \& D. Nunan (Eds.), Voices from the language classroom (pp. 145167). Cambridge: Cambridge University Press.

Weiner, B. (1985). Human motivation. New York: Springer-Verlag.

Williams, M., \& Burden, R. L. (1997). Psychology for language teachers: A social constructivist approach. Cambridge: Cambridge University Press.

Yashima, T. (2000). Orientations and motivation in foreign language learning: A study of Japanese college students. JACET Bulletin, 31, 121-133.

(Received May 14, 2000; revised November 11, 2000) 